\title{
Redescription of Bryconamericus rubropictus (Berg) n. comb. (Ostariophysi, Characidae) and reference to its secondary sexual dimorphism
}

\author{
Liliana BRAGA \\ Museo Argentino de Ciencias Naturales «Bernardino Rivadavia», Av. A. Gallardo 470, 1405 Buenos Aires, \\ Argentina. Invest. CIC. E-mail: lilbra@muanbe.gov.ar
}

\begin{abstract}
Albstract: Tetragonopterus rubropictus, briefly described by Berg based on specimens collected in the Molinos River, Salta, Argentina, was transferred to the genus Astyanax Baird \& Girard without comments by Eigenmann. Based on the study of type specimens and more extensive material, the species is redescribed. The species possesses the combination of characters that are currently used to define the genus Bryconamericus Eigenmann; thus, the species is transferred to this genus. Principal component analysis on twenty morphometric variables showed that caudal peduncle depth is deeper in adult males than in adult females, and that pelvic, pectoral, anal and dorsal fins are longer in males than in females. Bryconamericus rubropictus seems to be closely related to $B$. thomasi Fowler. Both species mainly share the enlarged anal fin of males with a strongly convex distal border. Bryconamericus rubropictus differs from $B$. thomasi by the presence of 14 scales around caudal peduncle (vs. 16), more teeth on smaller posterior dentary series (6-9 vs. 3-6) and some morphometric values. A lectotype is designated for $T$, rubropictus.
\end{abstract}

Key words: Characidae, Bryconamericus rubropictus, lectotype designation, Argentina.

Berg (1901) described Tetragonopterus rubropictus based on specimens collected in the Molinos River, northwestern Argentina. Berg's original description furnishes a reduced number of diagnostic characters. Eigenmann (1909) transferred this species without comments to the genus Astyanax Baird and Girard. Afterwards, Eigenmann (1927) reported a specimen from Cachi, a site close to the type locality, without outstanding additional information. Tortonese (1942) questionably cited A. rubropictus from the Pilcomayo River in Bolivia. Subsequent citations of this species (Ringuelet et al., 1967, Ringuelet, 1975, Arratia et al., 1983) were made without reference to additional specimens. On the basis of the type specimens and more extensive material, the species is redescribed and an account of its secondary sexual dimorphism is provided. Tetragonopterus rubropictus possesses the combination of characters that are currently considered diagnostic for the genus Bryconamericus Eigenmann and thus the species is transferred to it. Bryconamericus rubropictus is compared with its closest relative.

\section{MATERIALS AND METHODS}

Counts and measurements were made following Fink \& Weitzman (1974). Measurements were taken with a digital calliper $(0.01 \mathrm{~mm})$ and data registered to the nearest $0.1 \mathrm{~mm}$. Standard length (SL) is expressed in mm. All other measurements are expressed as percentages of SL except subunits of the head which are expressed as percentages of head length. For meristic values given in the description the range is given first followed by the mean $(x)$ and the value for the lectotype (in parentheses).

Principal component analysis (PCA) was used to analyse the covariation of morphometric variables. The components were calculated from the covariance matrix of logarithmic transformed data. After the evaluation of PCA, the variables on which the PC II and PC III loaded heavily were reanalysed as a function of SL (character/SL $\mathrm{x}$ 100 ) and analyses of variances (ANOVA's) were conducted on log-transformation of these ratios.

Osteological preparations were cleared and counter-stained for cartilage and bone following 


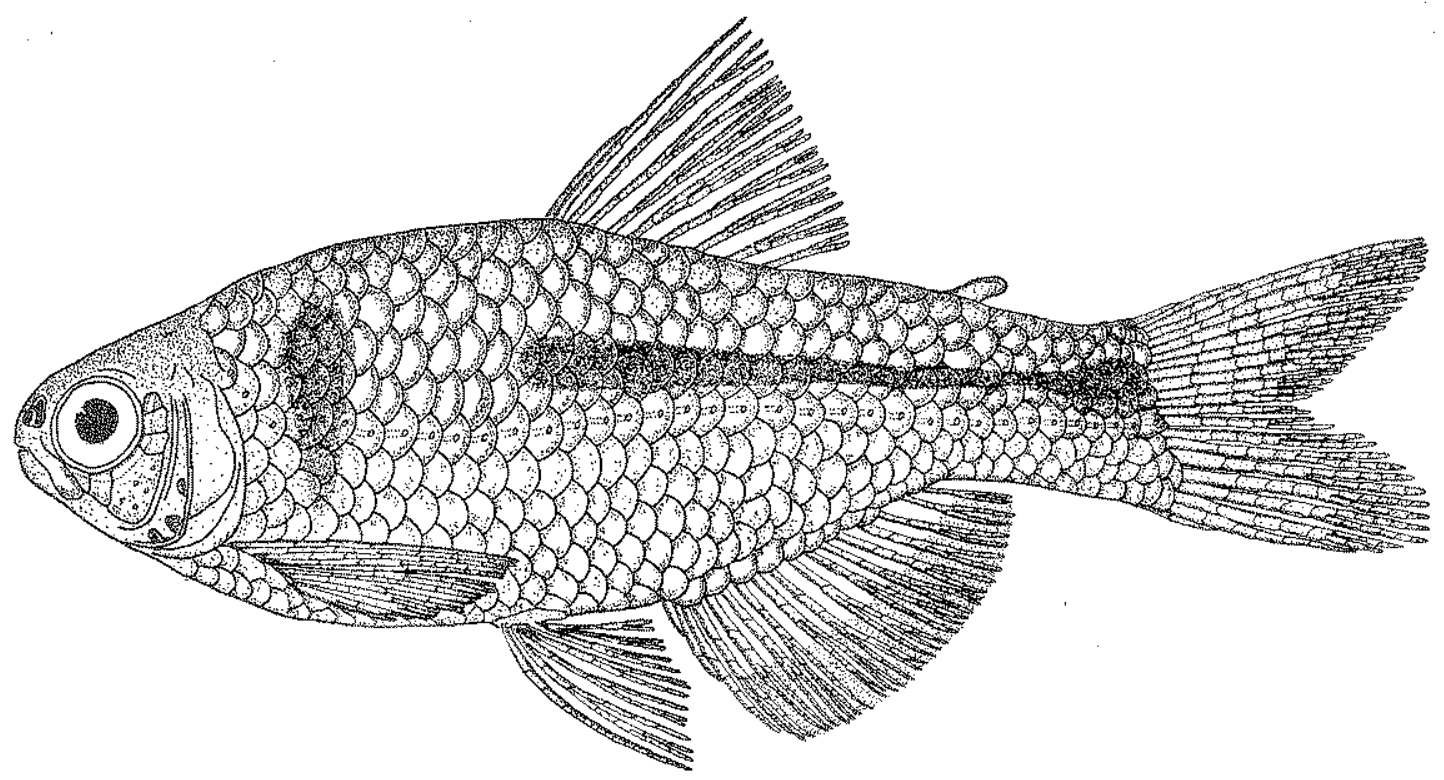

Fig. 1. Bryconamericus rubropictus (Berg) n. comb., male, $59.1 \mathrm{~mm}$ SL.

procedures modified from Taylor \& Van Dyke (1985). Vertebrae were counted from cleared and stained specimens only and include those of the Weberian apparatus; the compound terminal centrum was counted as a single element.

The specimens examined belong to the following institutions: Museo Argentino de Ciencias Naturales, Buenos Aires (MACN); Facultad de Ciencias Naturales y Museo, Universidad Nacional de La Plata (MLP).

Comparative material referred. Bryconamericus thomasi; all specimens come from Argentina: MACN 8053,8 spms. 2 spms. cleared and stained, Vado Hondo, Orán, Salta. MACN 8051, 6 spms., Lipeo River, Salta. MACN 8071, 1 spm., Libertador General San Martín, Salta.

\section{RESULTS}

Bryconamericus rubropictus (Berg, 1901) n. comb.

(Figs. 1-3, Tables 1-2)

Tetragonopterus rubropictus Berg, 1901: 305 (Type locality: Molinos River, Salta, Argentina).

Astyanax rubropictus, new combination, Eigenmann, 1909.

Description. Morphometric data are summarized in Table 1. Body compressed. Greatest body depth at dorsal fin origin. Dorsal profile of head straight or gently convex. Dorsal profile of body regularly convex from rear of head to dorsal fin origin, straight along dorsal fin base and nearly straight to adipose fin. Ventral profile of head and body slightly convex from symphysis of lower jaw to origin of pelvic fin, nearly straight to anal fin origin, and convex along base of anal fin. Caudal peduncle compressed. Dorsal and ventral profiles of caudal peduncle straight or slightly concave. Head length moderate, nearly one quarter of standard length. Snout rounded, shorter than orbital diameter. Six infraorbitals present. Ventral and posterior margin of third infraorbital in contact with preopercle. Frontoparietal fontanel reduced; frontals in contact only at epiphy.. seal bar; supraoccipital spine short. Upper jaw slightly larger and mouth barely subterminal or jaws equal and mouth terminal. Maxilla reaching slightly posterior to vertical line through anterior border of orbit. Maxilla with 3 to $5, \mathrm{x}$ : 4.1 (5) teeth. Anterior $2-4$ maxillary teeth comm pressed and tricuspidate, remaining teeth conical. Premaxilla with two rows of teeth. Outer row with $3-5, x: 3.9$ (3) tricuspidate teeth, subequal in size. Inner row with 4 broad teeth, the first with 4 cusps, the remaining ones with a prominent central cusp flanked by two pairs of cusps of decreasing size. Dentary with 4 large cuspidate teeth along anterodorsal margin of the bone, central cusp long and flanked by two pairs of 
smaller cusps, followed posteriorly by 6-9 smaller tricuspidate teeth except the last, conical. Six supraneural bones without expanded distal portion, or distal portion poorly developed. First dorsal fin pterygiophore between neural spines of $12^{\circ}$ and $13^{\circ}$ vertebrae. Dorsal fin rays ii-iii, 8 (ii, 8), last unbranched ray and first and second branched rays longest. Anal fin rays iii-v, 13-17, $x$ branched rays: 15.5 (iii, 15 ). Males with last unbranched ray and anterior 6-9 anal fin rays longest, subequal in length; remaining rays becoming progressively shorter posteriorly and distal border of anal fin sharply convex (see Fig. 1). Temales with anterior $2-3$ branched anal fin rays longest, following rays progressively decreasing posteriorly along fin, and distal border of anal fin straight or somewhat emarginate. Anal fin of males with long hooks on last unbranched ray and 6-9 branched rays; hooks proximally directed, $1-2$ per segment. Pectoral fin rays $i, 9-13$, $x$ branched rays: 11.5 (i, 11). Pelvic fin rays are invariantly i, 7 (damaged in lectotype). Pelvic fin of males with long ventromedial retrorse bony hooks on all branched rays; $1-2$ pairs of hooks per segment. Caudal fin forked, lobes rounded and equal in length. Lateral line with 35-39 perforated scales, $x: 37$ (36). Scale rows in vertical series between dorsal fin and lateral line 5-6, $\mathrm{x}$ : 5.8 (6). Scale rows between lateral line and pelvic fin origin, 4-6, x: 5 (5). Predorsal scales, 11$14, x: 13,(13)$, usually in a regular series. Scale rows around caudal peduncle, 14. Caudal fin scaled only at fin base. Anal sheath with a single row of $8-12$ scales. Total vertebrae: $35-36$; caudal vertebrae: 18-19. Total number of gill rakers on first arch, 9-10.

Color in alcohol. Overall coloration yellowish tan, darker on dorsal portions of head and body. Head with dark chromatophores dorsally and anteriorly. Scattered chromathophores on maxilla, infraorbital bones and lower jaw. Scale margin on dorsolateral portion of body above lateral line outlined by series of small dark chromatophores forming a reticulate pattern. Anteroventral portion of body with scattered chromatophores. A dark humeral spot vertically

Table 1. Morphometric data for Bryconamericus rubropictus (Berg) n. comb. Standard length (SL) is expressed in mm. Measurements 1 to 19 are percentages of SL, 20 to 24 are percentages of head length. $N=34$ (16 males and 18 females). $\mathrm{SD}=$ standard deviation.

\begin{tabular}{lcccc}
\hline Character & Lectotype & Range & Mean & SD \\
\hline Standard length (mm) & 59.1 & $44.4-57.2$ & 50.1 & 3.502 \\
1 Body depth & 29.7 & $28.3-37.0$ & 32.3 & 2.950 \\
2 Predorsal length & 48.3 & $46.8-55.0$ & 51.8 & 2.062 \\
3 Prepectoral length & 26.2 & $23.8-28.0$ & 25.7 & 0.916 \\
4 Prepelvic length & 47.3 & $42.3-49.0$ & 46.4 & 1.754 \\
5 Preanal length & 65.4 & $59.9-66.6$ & 63.5 & 1.828 \\
6 Caudal peduncle depth males & 12.6 & $11.3-15.5$ & 13.2 & 1.394 \\
7 Caudal peduncle depth females & - & $9.8-13.3$ & 10.8 & 0.962 \\
8 Caudal peduncle length & 16.9 & $15.1-21.2$ & 18.1 & 1.441 \\
9 Pectoral fin length males & 20.6 & $20.0-25.8$ & 23.4 & 0.878 \\
10 Pectoral fin length females & - & $16.6-23.4$ & 20.6 & 1.607 \\
11 Pelvic fin length males & - & $16.3-21.3$ & 18.3 & 1.379 \\
12 Peivic fin length females & - & $14.2-18.0$ & 15.5 & 1.225 \\
13 Dorsal fin length males & 21.4 & $19.7-25.6$ & 21.6 & 1.881 \\
14 Dorsal fin length females & - & $17.3-23.8$ & 20.2 & 1.598 \\
15 Anal fin length males & 20.1 & $17.6-20.6$ & 19.2 & 1.222 \\
16 Anal fin length females & - & $14.3-18.2$ & 16.1 & 0.783 \\
17 Dorsal fin base & 10.6 & $10.5-14.1$ & 12.9 & 0.877 \\
18 Anal fin base & 22.6 & $19.1-24.7$ & 21.4 & 1.708 \\
19 Head length & 25.0 & $22.3-25.8$ & 24.2 & 0.907 \\
20 Snout length & 22.8 & $20.1-24.6$ & 22.2 & 1.272 \\
21 Orbital diameter & 33.1 & $32.8-39.1$ & 37.0 & 1.650 \\
22 Postorbital length & 44.2 & $39.0-44.6$ & 42.4 & 1.347 \\
23 Interorbital width & 33.7 & $29.0-37.5$ & 33.3 & 1.754 \\
24 Upper jaw length & 35.1 & $30.0-37.2$ & 33.5 & 1.723 \\
\hline
\end{tabular}



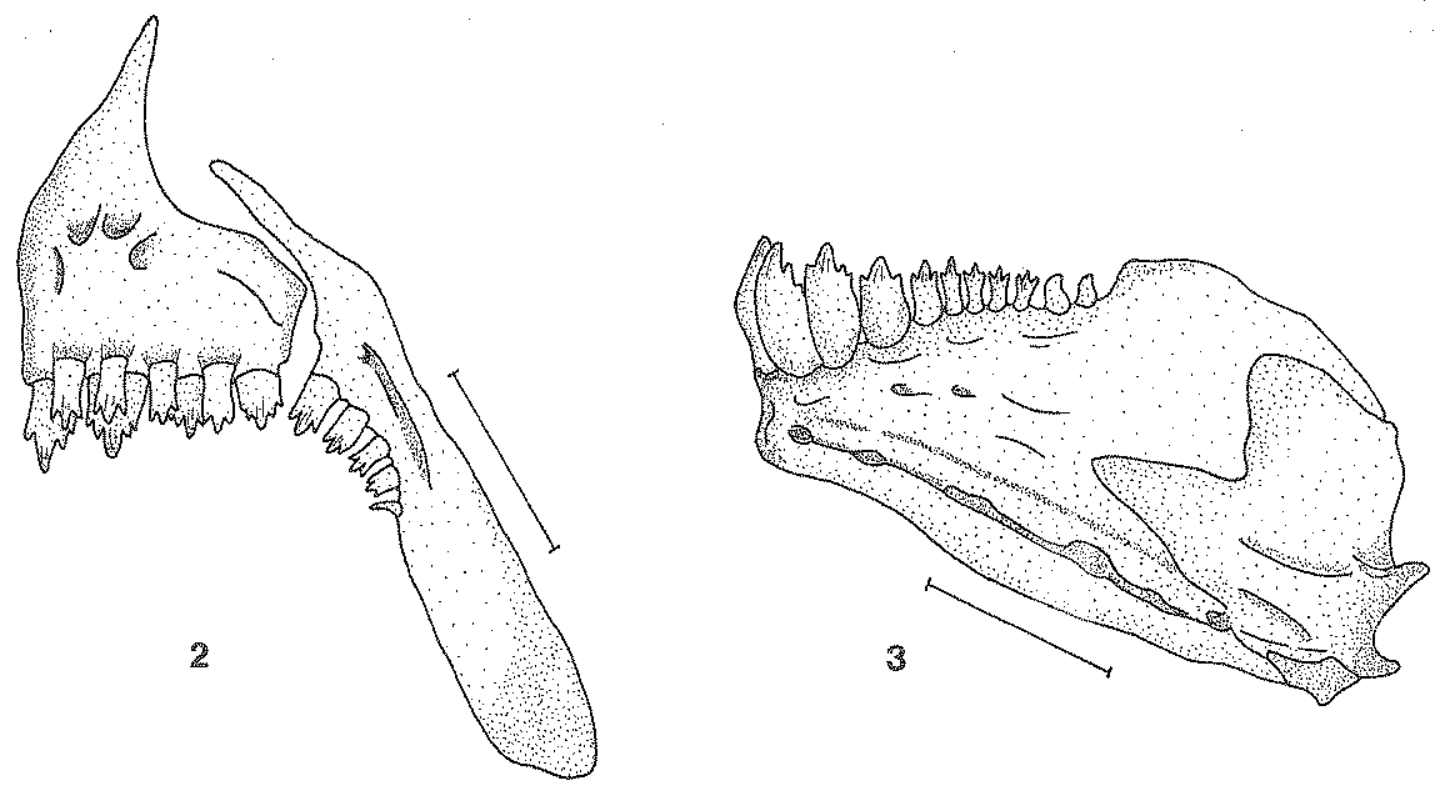

Figs. 2-3. Bryconamericus rubropictus (Berg) n. comb. 1, Upper jaw, left side, lateral view, 2, Lower jaw, left side, lateral view. Scale bar $=1 \mathrm{~mm}$.

elongate. A mid-lateral stripe of dark pigmentation extending posteriorly from a vertical line through origin of dorsal fin to caudal peduncle; stripe narrow anteriorly and progressively widening posteriorly, not extending onto middle caudal rays of caudal fin. Dorsal fin rays outlined by small dark chromatophores; scattered pigment on membranes. Dorsalmost rays of pectoral fin dark pigmented. The distal portions of interradial membranes of the anal and caudal fins somewhat dusky, Pelvic fins unpigmented.

Sexual dimorphism in morphometric characters. Principal component analysis was used to examine patterns of morphometric variation among the two sexes. The results of these analyses for 20 morphometric variables from 35 specimens (17 males and 18 females) are summarized in Table 2. The first principal component (PC I) accounts for $68.18 \%$ of the total variance whereas the second principal component (PC II) explains $11.93 \%$, and the third (PC III), 5.18\%. The loadings on PC I are all positive and of roughly similar magnitude; PC I can be interpreted as a general size factor. However, the loadings on it are somewhat unequal particularly that by pelvic fin length; its use as a size axis therefore conceals some shape information. The subsequent components are bipolar with sizeable variable loadings. Characters with the highest loadings on PC II involve caudal peduncle depth, pelvic fin length, anal fin length and pectoral fin length.
Table 2. Principal component loadings for 20 morphometric characters of Bryconamericus rubropictus (Berg) n. comb.

\begin{tabular}{lccc}
\hline Character & PC I & PC II & PC III \\
\hline Standard length & 0.031 & -0.013 & 0.003 \\
Body depth & 0.039 & -0.002 & -0.004 \\
Predorsal length & 0.032 & -0.013 & 0.001 \\
Prepectoral length & 0.031 & -0.010 & 0.005 \\
Prepelvic length & 0.029 & -0.014 & 0.005 \\
Preanal length & 0.028 & -0.017 & 0.010 \\
Caudal peduncle depth & 0.045 & 0.037 & 0.006 \\
Caudal peduncle length & 0.032 & -0.007 & -0.003 \\
Pectoral fin length & 0.036 & 0.019 & -0.009 \\
Pelvic fin length & 0.053 & 0.025 & -0.015 \\
Dorsal fin length & 0.025 & -0.017 & -0.034 \\
Anal fin length & 0.044 & 0.023 & -0.004 \\
Dorsal fin base & 0.036 & -0.016 & -0.003 \\
Anal fin base & 0.043 & 0.010 & -0.003 \\
Head length & 0.037 & -0.011 & 0.002 \\
Snout length & 0.046 & -0.013 & -0.002 \\
Orbital diameter & 0.030 & -0.007 & -0.007 \\
Postorbital length & 0.040 & -0.011 & -0.005 \\
Interorbital width & 0.040 & -0.011 & -0.005 \\
Upper jaw length & 0.037 & -0.007 & 0.015 \\
\% variance explained & 68.18 & 11.93 & 5.18 \\
\hline
\end{tabular}

PC III is only heavily loaded on dorsal fin length. A scatter plot of individual scores on PC I and PC II (Fig. 4) provides a nearly complete separation between males (2.0-0.06) and females $(-1.89$. 


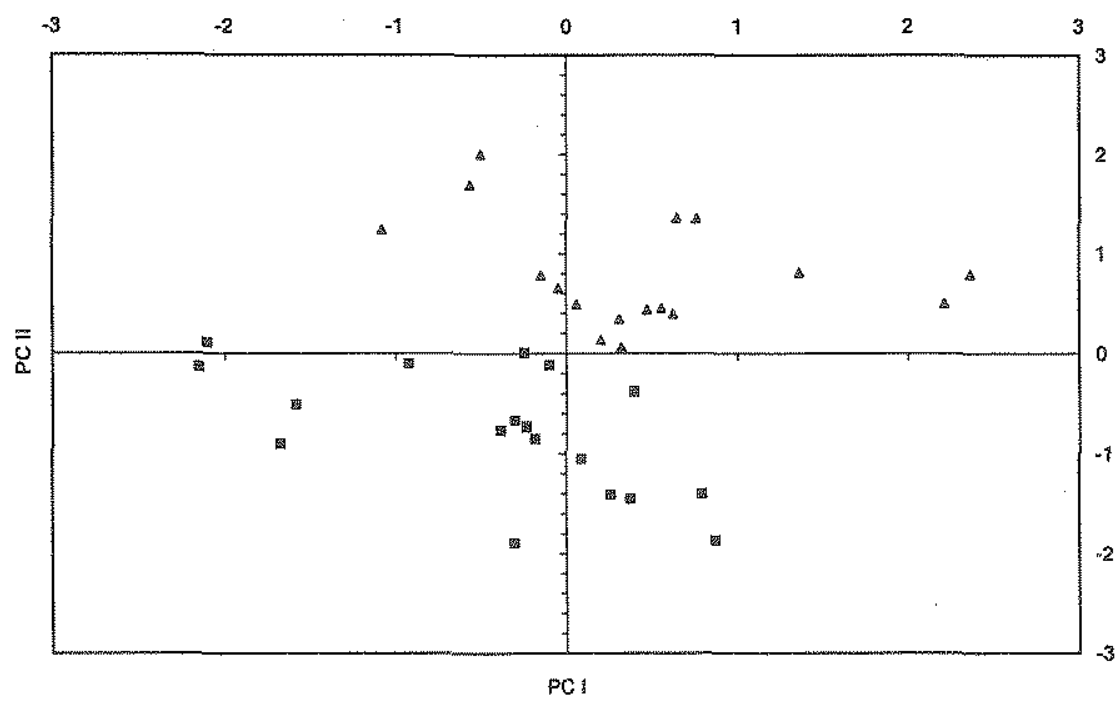

Fig. 4. Scatterplot of individual scores on first two principal components (PC I, PC II) for 20 morphometric variables of Bryconamericus rubropictus (Berg) n. comb. Triangles: males, $(\mathrm{N}=17)$; squares: females $(\mathrm{N}=18)$.

0.11). PC II represents a contrast between caudal peduncle depth, which is relatively deeper in males, and length of the pectoral, anal and pelvic fins, each of which is relatively longer in males. ANOVA's revealed that males and remales are significantly different from one another for caudal peduncle depth, pectoral fin length, anal fin length and pelvic fin length $(P<0.01)$, and dorsal fin length $(\mathrm{P}<0.05)$.

Distribution Upper portions of PasajeJuramento River system, northwestern Argentina, (approx. $24^{\circ}-27^{\circ} 20^{\prime} \mathrm{S}, 64^{\circ} 40^{\prime}-66^{\circ} 48^{\prime} \mathrm{W}$ ).

Type and non-type material examined. All specimens come from Argentina. MACN 5165, lectotype of Tetragonopterus rubropictus by present designation (male, $51.9 \mathrm{~mm}$ SL), Molinos River, Salta (ex Los Andes, in part), (approx. $25^{\circ}$ $28^{\prime} \mathrm{S}, 66^{\circ} 23^{\prime} \mathrm{W}$ ), col H. Hubert, 12-2-1901. MACN 5165 , paralectotypes of $T$. rubropictus, 2 spms. (52.9-45.4 mm SL), collected with lectotype. MACN 5171, paralectotypes of T. rubropictus, 2 spms. (61.1-45.5 mm SL), collected with lectotype. MACN 5158, $1 \mathrm{spm}$. (52.8 mm SL), Santa María River, Salta. MACN 8230, 17 spms. (47.3$28.0 \mathrm{~mm}$ SL), Guachipas River at Alemanía, Salta. MLP 5-V-46-8, 6 spms. (50.1-44.4 mm SL), Arenales River, Salta. MLP 24-XI-39-5, 9 spms. (55.8-44.9 mm SL), Santa María River, Catamarca. Cleared and stained specimens: 1 spm. (45.0 mm SL), Calchaquí River at San Carlos, Salta; 2 spms. (40.1-36.0 mm SL), Santa María River, Catamarca.

\section{DISCUSSION}

Berg's original description of Tetragonopterus rubropictus was based on eight specimens collected in the Molinos River, a tributary of the Calchaquí River, Salta province. Only five specimens have been located in MACN holdings (Braga \& Piacentino, 1994). These specimens are in a rather poor condition at this time. The syntype in the best overall condition (MACN $5161,51.9 \mathrm{~mm} \mathrm{SL}$, male) is designated as the lectotype; the four remaining syntypes become paralectotypes.

The original description of $T$. rubropictus referred only to the following characters: overall body form and coloration, number of scales in a lateral series, number of fins rays and number of maxillary teeth. The species was transferred to the genus Astyanax Baird \& Girard by Eigenmann (1909). The presence in this species of the following characters: two rows of teeth on the premaxilla with four teeth in the inner series, dentary with a single row of teeth, a low number of teeth (0-6) along anterolateral margin of maxilla, caudal fin scaled only at base, a complete laterosensory canal system on the body, a third infraorbital well developed and contacting the preopercle along its ventral and posterior margin allow the inclusion of this species in Bryconamericus Eigenmann. There are some doubts that the genus represents a natural group within Characidae and this has been expressed 
several times (e.g. Vari \& Siebert, 1990, Malabarba \& Malabarba, 1994). Like most specious tetragonopterine genera, Bryconamericus is currently defined by a combination of characters (Eigenmann, 1917, 1927, Géry, 1977) and based on the current diagnoses of this genus, $T$. rubropictus is consequently transferred to it.

A similar enlarged anal fin with strongly convex distal border in males as described for $B$. rubropictus is also present in B. thomasi Fowler (compare Fig, 1 with Fowler, 1940, Fig. 3), a species that has been recently redescribed by Miquelarena \& Aquino (1995). Additionally, both species are similar in the general color pattern and some counts and measurements. Bryconamericus rubropictus can be discriminated from $B$. thomasi by differences in the number of scales around the caudal peduncle (14 vs. 16), the number of teeth on the smaller posterior dentary series (6-9 vs. 3-5), and a smaller relative length of the snout (21.1.24.6\% of head length, $\mathrm{x}: 22.2$ vs. $24.0-27.4$, x: 25.9$)$. Furthermore, the caudal peduncle depth, pectoral fin length, pelvic fin length and dorsal fin length do not differ significantly between males and females of $B$, thomasi $(P>0.05)$ as they do in $B$. rubropictus. It is here suggested that $B$. rubropictus and B. thomasi are both putative distinct species rather than geographically recognizable variant populations of $B$. rubropictus, at least until more population samples of both species through their area of distribution (upper Juramento River basin for B. rubropictus and Pilcomayo River and Bermejo River for $B$. thomasi) become available.

Tortonese (1942) questionably cited $B$. rubropictus from the Pilcomayo River in San Francisco, Bolivia, an area outside the presently known range of this species, and it is presumed a misidentification. Ringuelet (1975) reported specimens of $B$. iheringi (Boulenger) from Santa Maria River, Catamarca. Examination of the specimens that serve as the basis for this record indicates that they are individuals of $B$. rubropictus.

\section{BIBLIOGRAPHY}

Arratia, G., M.B. Peñafort \& S. Menú Marque. 1983. Peces de la región sureste de los Andes y sus probables relaciones biogeográficas actuales. Deserta 7: 48-107.
Berg, C. 1901. Comunicaciones ictiológicas IV. Com Mus. Buenos Aires 9: 293-311.

Braga, L. \& G. L. M. Piacentino. 1994. Lista de los tipos de peces actuales depositados en el Museo Argentino de Ciencias Naturales "Bernardino Rivadavia”. Rev. Mus. Arg. Cs. Nat, Zool. 16(8); 97-108.

Eigenman, C.H. 1909. The freshwater fishes of Patagonia and an examination of the Archiplata Archelenis theory. In: Reports of the Princeton Expedition to Patagonia 1896-1899, 3(1): 225-374.

- 1917. The American Characidae. Mem. Mus. Comp. Zool. Harvard 43(1): 1,102.

- 1927. The American Characidae. Mem. Mus. Comp. Zool. Harvard $43(3)$ : 311+428.

Fink, L. \& S.H. Weitzman 1974. The so-called Cheirodontin fishes of Central America with dem scriptions of two nets species. Srnithson. Contrib. Zool. 172: 1.46 .

Fowler, H.W. 1940. Zoological results of the second Bolivian expedition for the Academy of Natural Sciences of Philadelphia 1936-1937. The fishes. Proc. Acad. Nat. Sci. Philadelphia 42: 43-103.

Géry, J.J. 1977. Characoids of the Word. T.F.H. Publications, Neptune City, 672 pp.

Malabarba, M.C.S.L. \& L.R. Malabarba. 1994. Hypobrycon maromba a new genus and species of characiform fish from the upper rio Uruguai, Bra" zil (Ostariophysi: Characidae). Ichthyol. Explor. Freshwaters 5(1): 19-24.

Miquelarena, A.M. \& A.E. Aquino. 1995. Situación taxonómica y geográfica de Bryconamericus thomasi Fowler, 1940 (Teleostei, Characidae). Reu. Brasil. Biol. 55(4): 559-569.

Ringuelet, R.A. 1975. Zoogeografía y ecología de los peces de aguas continentales de la Argentina y consideraciones sobre las áreas ictiológicas de América del Sur. Ecosur 2(3): 1-122.

Ringuelet, R.A., R.H. Arámburu \& A. Alonso de Arámburu. 1967. Los peces argentinos de agua dulce. Comisión de Investigaciones Científicas de la Provincia de Buenos Aires, La Plata, 602 pp.

Taylor, W.R. \& G.C. Van Dike. 1985. Revised procedures for staining and clearing small fishes and other Vertebrates for bone and cartilage. Cybium $9(2): 107-119$

Tortonese, E. 1942. Ricerche de osservazioni sui Characidi delle Sottofamiglie Tetragonopterinae, Glandulocaudinae e Stetaprioninae (Teleostei, Plectospondyli), Bull. Mus. Zool. Anat. Comp. Torino 49: 11-76.

Vari, R.P., \& D.J. Siebert. 1990. A new, unusually sexually dimorphic species of Bryconamericus (Pisces: Ostariophysi: Characidae) from the Peruvian Amazon. Proc. Biol. Soc, Wash. 103(3): 516-524.

Recibido: 4-VII-2000 Aceptado: 29-VIII-2000 